\title{
Social Meanings in School Linguistic Landscape: A Geosemiotic Approach
}

\author{
ERNA ANDRIYANTI \\ Universitas Negeri Yogyakarta, Jalan Colombo No. 1 Karangmalang, 55281 Yogyakarta, Indonesia \\ erna.andriyanti@uny.ac.id
}

Published online: 29 October 2021

To cite this article: Erna Andriyanti. 2021. Social meanings in school linguistic landscape: A geosemiotic approach. KEMANUSIAAN the Asian Journal of Humanities 28(2): 105-134. https://doi.org/10.21315/kajh2021.28.2.5

To link to this article: https://doi.org/10.21315/kajh2021.28.2.5

\begin{abstract}
As an approach to multilingualism, the study of linguistic landscape (LL) in educational settings is still underexplored. LL study is significant to disclose various aspects of language existence and use. In the school context, it might reveal what and how languages are used among school members and their relevance to education. This article aims to examine the emerging themes of signs' messages in school LL and the contribution of multimodal social semiotic elements to the signage social meanings. It studied 890 signs from five senior high schools in Yogyakarta, Indonesia and used a geosemiotic approach to analyse the verbal and visual texts. The findings reveal eight major themes of messages: (1) location or place direction, (2) morality and religion, (3) environment and energy, (4) school identity and information, (5) activities, (6) how to comport oneself, (7) science and knowledge and (8) rules, regulations and acts. The three main modes (language, image and colour) in the school LL serve the functions to communicate and to represent the schools' social reality relevant to the emerging themes through iconic and symbolic semiotic systems. The school LL is a multifaceted social construct that also reveals the relationship between the sign makers and the addressees.
\end{abstract}

Keywords and phrases: linguistic landscape multimodal, social semiotic analysis, multilingualism, icon, symbol

\section{Introduction}

Since it was firstly introduced as "the language of public road signs, advertising billboards, street names, commercial shop signs and public signs on government buildings" (Landry and Bourhis 1997, 25), linguistic landscape (hereafter LL) is commonly defined as the use of written language for public communication (Cenoz and Gorter 2008; Gorter 2006a; 2013). The languages employed in 
LL might vary and even though language is primarily used in LL, the use of other modes such as images, colour, as well as font size is important to be considered to understand the messages conveyed through the signs. LL is both multilingual and multimodal (Cenoz and Gorter 2008; Hewitt-Bradshaw 2014; Lotherington 2013). The modality implies various functions borne by different modes used in LL (Kress 2010).

The fast-growing body of LL research has revealed numerous aspects of language use and existence in particular public space as well as its potential benefit (Backhaus 2006; Cenoz and Gorter 2008; Huebner 2006). For example, Backhaus (2006) concludes that the official and non-official multilingual signs in Tokyo respectively indicate power and solidarity and correspond to the languages contained and their arrangement in the signs. Huebner (2006) found hegemony of English in Bangkok's LL. LL in a laboratory might represent personal, professional and communal identities (Hanauer 2010). Besides functioning as a means of communication, LL can be used positively as language learning and literacy resource and exposure to increase language sensitivity and awareness (Cenoz and Gorter 2008; Hewitt-Bradshaw 2014; Lotherington 2013; Sayer 2010).

Despite its fast development, LL research in Indonesian context-more especially in the educational setting - has not been much conducted nor published. Among those few published works are da Silva (2014) and Fakhiroh and Rohmah (2018), which deal with city LL of Jakarta and Sidoarjo, respectively. Other two studies analyse school LL in Jakarta (Harbon and Halimi 2019) and that in Yogyakarta (Andriyanti 2019), which is an earlier published work from the same collected data as this present study.

Some elements of LL important to be studied, among others, are who the sign makers make what signs where in what languages and why (Marten, Mensel and Gorter 2012). Based on the makers, LL signs can be categorised as "top-down" LL items and "bottom-up" LL items (Ben-Rafael et al. 2006). Top-down indicates authorities or policy makers whilst bottom-up shows social actors or individuals. As "a verbal-visual amalgamation" (Malinowski 2010), both language and image in LL contribute to the meaning-making.

This present study focuses on the social meanings in senior high school LL in multilingual Yogyakarta. Because the use of various languages, such as Indonesian language (locally known as bahasa Indonesia), English and Arabic as well as the local language Javanese and other foreign languages in the school LL is pervasive, an analysis of the signage might reveal various aspects of communications among 
the school members and outsiders. This study is intended to raise scholars' awareness that research of school LL signs is significant because school signs might serve numerous functions. The objectives of this current research are to explain the themes that embody the meanings or messages conveyed through the signs at the school LL and how multimodal social semiotic elements contribute to the signs' social meanings. The discussion of meanings or messages here is based on categorisation of the emerging themes.

\section{Literature Review}

A number of LL studies conducted in different geographical areas focus on school signage and most of them are descriptive. They collected the data through capturing the sign pictures digitally and discuss various aspects. For instance, Andriyanti (2019) scrutinised 890 school signs from five senior high schools in Yogyakarta, Indonesia to find the lingual patterns and LL representation. Harbon and Halimi (2019) investigated messages about food and nutrition through 187 data from 20 schools in Jakarta and Depok education districts, also in Indonesia. Brown (2012) collected the data through interview, observation and ethnography from kindergarten and elementary schools in Southeastern Estonia for over a decade to reveal the importance of the existence of lesser-used language for its revitalisation. Przymus and Kohler (2018) found the connections between particular languages in signs indexing 30 school neighbourhoods in Tucson, Arizona, social wealth and opportunities for bilingual education. Andriyanti (2019), Brown (2012) and Harbon and Halimi (2019) on one side found the language situation reflected in school LL, showing both vital and less-used languages in school environment. All four studies emphasised that the findings must be taken seriously because what are conveyed or represented in school LL are influential, especially to school members and the surrounding neighbourhoods.

In analysing the school LL social meanings or messages, Peirce's semiotic principles are adopted, especially those related to sign types (Hoopes 1991). Based on this system, a sign might be iconic, indexical and symbolical. An icon is a sign which represents its object in resembling it; an index represents its object by being actually connected with it; a symbol represents its object through interpretation. What is emphasised in this article is that indexicality (dependency of signs on context) is the property owned by all types of signs (Scollon and Scollon 2003). Kallen $(2010,41)$ states, "studies of the LL generally start from the assumption that signage is indexical of more than just the ostensive message of the sign". Scollon and Scollon (2003) argue that the meaning of a sign depends on where and when the sign is placed and they call this social semiotic 
perspective "geosemiotics". This present study uses this approach, which is considered by Gorter $(2013,194)$ as "a theoretical push" to the study of LL. Therefore, the most prioritised element of context in construing meaning of a sign in this school LL study instead of language is the location of the sign rather than any other elements such as image, colour, font size or shape and sign size or type. Iconicity and symbolism are discussed due to their relevance to social meanings.

The discussion of the meanings or messages categorised in the emerging themes is based on the interconnection between the three main systems of geosemiotics: interaction order, visual semiotics and place semiotics (Scollon and Scollon 2003). Among the three main hidden dimensions of interaction order, interpersonal distances: intimate, personal, social and public are considered the most significant in this study due to the relationship between participants involved in the communications through the school signs. Hence, the people addressed in the signs are significant to be considered. Sense of time as the second dimension is discussed when relevant because generally, the data were collected in the same short time period. The third, perceptual spaces are considered to overlap with place semiotics. Related to visual semiotics, the focus is on how the interaction order is represented visually and how the placement of modes (languages, images and colours) might influence interpretation. With regard to place semiotics, this study focuses on inscription and emplacement.

Since LL is a means of public communication, the social semiotic approach to the use of language and other modes as a sign system is used to interpret the social reality of the school LL signage. Based on this approach, language is seen not only as a means of communication but also as playing roles in the "social construction of reality" (Chandler 2007, xv), to which other modes also contribute. The social semiotic approach to multimodality has three basic assumptions (Bezemer and Jewitt 2010), all of which are meaningful to analyse the present research data. First, the use of multiplicity of modes contributes to meaning in communication and representation. Kress (2010) stresses that each mode has a particular function. Second, all modes (including the use of different languages in a sign) are bound with their cultural, historical and social contexts. To illustrate, Periasamy, Gruba and Subramaniam (2015) account a sociocultural context to analyse the meanings of modes in a television commercial. Third, meanings conveyed by any mode are interwoven with those of other modes in the same sign. This multimodal social semiotic approach is therefore useful to understand the sociocultural contexts of the examined signs (Gorter 2006b). Due to the central role of language in LL to communicate, the interpretation of meanings or messages in this study is mainly based on the verbal texts and next on other modes that is images and colour. 
Language as a social sign system is not interpreted randomly due to history and connotation (Chandler 1994) and interdependent relations between the elements of sign (Keane 2003). In Kress' words, a sign as a relationship between form(s) and meaning is motivated by the maker's interest (2010). Based on these principles, it is believed that the school sign makers are aware of using language alone or combining modes to convey messages through particular signs, which in turn are interpreted by the target audience in accordance with conventions understood through relations among the sign elements.

To sum up, this present study applies a perspective called geosemiotics, which is "the study of the meaning systems by which language is located in the material world" (Scollon and Scollon 2003, x) to reveal the emerging themes of the school LL and the social meanings by focusing on the contribution of various modes, namely language, visual image and colour. The applied approach has three basic assumptions proposed by Bezemer and Jewitt (2010).

\section{Research Methods}

This article reports a part of a larger study titled "Linguistic Landscape in Senior High Schools as Representation of Language Situation in Yogyakarta's Multilingual Context", focusing on social meanings; the other part discusses lingual patterns and representation (see Andriyanti 2019). The social meanings with regard to the themes were determined by the signs' indexicality and framed with the three systems of geosemiotics. The contributions of the three main modes to the social meanings are connected to their iconicity and symbolism and to the emerging themes.

A total of 890 indoor and outdoor signs from five senior high schools in Yogyakarta, Indonesia were captured with digital cameras and categorised based on each school. This number excludes signs containing abbreviations or letters which do not compose words due to problems in identifying the language used. Data distribution at the schools - coded as A1, A2, A3, A4 and A5-is as follows. 
Table 1. Data distribution by school

\begin{tabular}{lcl}
\hline School & Number of data & Range of data \\
\hline A1 & 178 & Data 1-178 \\
A2 & 276 & Data 179-454 \\
A3 & 122 & Data 455-576 \\
A4 & 134 & Data 577-710 \\
A5 & 180 & Data 711-890 \\
\hline Total & 890 & \\
\hline
\end{tabular}

The selection of those schools was based on their availability and criteria sampling. Three schools represented those under the Ministry of Education and two schools under the Ministry of Religion. A1 and A2 were Islamic public schools, A3 general private, A4 general public and A5 vocational public. Different from general schools, which teach only one subject of religious education, the Islamic schools teach several religious subjects such as the Quran, the Hadiths, Islamic Jurisprudence, Arabic Language and Worshipping. Public schools are those state-owned.

\section{Procedures of data collection}

In the data collection (April to June 2018), photos of the signs were taken and notes relevant to the pictures were provided in the data sheets. The variables in the coding scheme include the verbal text, images, location and colour (see Ben-Rafael et al. 2006; Gorter 2006a). The verbal texts in the signs were the main data, while non-verbal texts, such as images, location and colour, were the supporting data. The list of data was compiled in a data sheet (as shown in Table 2).

The data were validated by two research assistants to check that all verbal texts matched the photos and no data were used more than once. One board, panel board, billboard, banner or poster, regardless its size and number of lingual units, was considered as one sign and analysed as a single datum. The coding system shows the school and datum number. For instance, A2/376 means the sign was found in School A2 and numbered 376 out of 890 data. 
Table 2. Example of data sheet

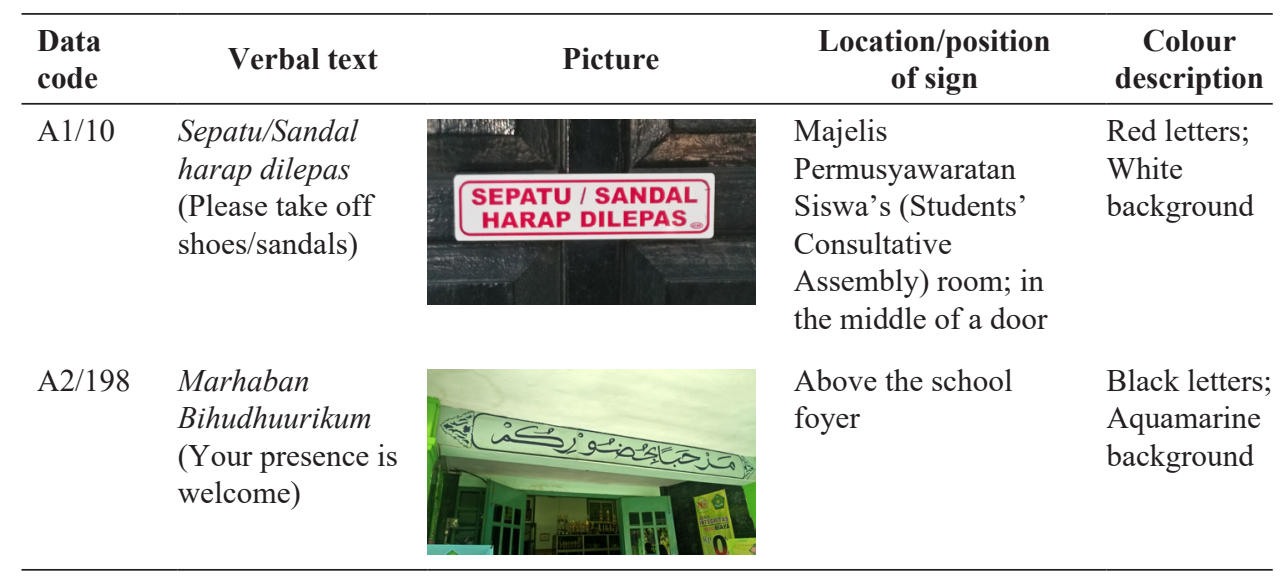

\section{Procedures of data analysis}

The verbal texts together with the contexts were identified based on similarities to find any emerging themes. The context - especially the visual image and location-in some signs significantly determines a theme because naturally there is no one-to-one relation between a signifier and the signified (Chandler 1994). An Indonesian monolingual sign saying, Orang beriman membuang sampah pada tempatnya, which literally means "A person of faith puts rubbish in a dustbin" may belong to three different themes: morality and religion, environment and energy and how to comport oneself. With regard to visual and place semiotics, that is the picture of a dustbin in the sign and its location in public space, not in or around a praying area, the sign was categorised into environment and energy theme. The emerging themes are divided into major (occurrence of $\geq 5 \%$ ) and minor (occurrence of $\leq 5 \%$ ) themes. To test the consistency of data analysis done by the researcher, analyst triangulation was applied (Patton 1999). First, the research assistants were trained on how to categorise the data into the emerging themes and the three modes identified by the researcher. Then they analysed the data, cross-checked the results and together with the researcher discussed some problematic results of analysis. At this point, an agreement was reached to determine the final results. The analysed three modes (language, image and colour) in the school LL that contribute to social meanings are tabulated across the emerging themes. Data quantification as a common practice in LL studies (Backhaus 2006; Ben-Rafael et al. 2006; Gorter 2006a) was done with regard to occurrences of themes and distribution of languages, images and colours. Statistical Package for the Social Sciences (SPSS) version 25 was used to get the accuracy of results in terms of frequency and percentage. 
For further interpretation of the social meanings, the three geosemiotic systems were applied. Categorising the modes into icon or symbol was also done to reveal the social construction represented by the LL signs.

\section{Results and Discussion}

Prior to presented results, following are language policies implemented in Indonesia's school context. The national language, Indonesian is mandatory to be used as the language of instruction and taught as a subject in all school levels (Act No. 20 2003; Act No. 24 2009). Based on Act No. 24 (2009), Indonesian is also compulsory to be used in public signs and facilities, including street signs, banners and other information mediums. English and Arabic might be used as mediums of instruction to support the teaching and learning of those languages (Act No. 20 2003; Act No. 24 2009). Arabic is a compulsory subject in Islamic schools (Decree No. 207 2014). The local language Javanese is optionally used as an instructional language in early stage of education (Act No. 20 2003). Javanese is also taught as a school subject with minimum meeting hours. All these policies are consequently relevant to the research results, especially related to the emergence of languages used to convey the school signs' meanings.

\section{Results}

Following are the results related to meanings or messages based on the emerging themes and the contribution of modes to the social meanings in the school LL signs.

\section{The themes in the school $L L$}

Eight major themes (691 data or 77.6\%) and eight minor themes (199 data or $22.4 \%$ ) were found in the school LL. The major themes are those with minimum frequency of $5 \%$ out of the whole data; the minor themes have frequency less than 5\%. Tables 3 and 4 present the major and minor themes' divide and their distribution by school. 
Table 3. Major themes

\begin{tabular}{llccccccc}
\hline No. & Themes & $\begin{array}{c}\text { School } \\
\text { A1 }\end{array}$ & $\begin{array}{c}\text { School } \\
\mathbf{A 2}\end{array}$ & $\begin{array}{c}\text { School } \\
\mathbf{A 3}\end{array}$ & $\begin{array}{c}\text { School } \\
\mathbf{A 4}\end{array}$ & $\begin{array}{c}\text { School } \\
\text { A5 }\end{array}$ & Total & Percentages \\
\hline 1 & $\begin{array}{l}\text { Place direction or } \\
\text { location }\end{array}$ & 32 & 48 & 39 & 11 & 34 & 164 & 18.4 \\
2 & Morality and religion & 26 & 41 & 3 & 13 & 37 & 120 & 13.5 \\
3 & $\begin{array}{l}\text { Environment and } \\
\text { energy }\end{array}$ & 11 & 48 & 8 & 18 & 16 & 101 & 11.3 \\
4 & $\begin{array}{l}\text { School identity and } \\
\text { information }\end{array}$ & 22 & 20 & 9 & 16 & 17 & 84 & 9.4 \\
5 & $\begin{array}{l}\text { Academic and non- } \\
\text { academic activities }\end{array}$ & 13 & 20 & 11 & 8 & 17 & 69 & 7.8 \\
6 & $\begin{array}{l}\text { How to comport } \\
\text { oneself }\end{array}$ & 14 & 14 & 4 & 8 & 17 & 57 & 6.4 \\
7 & $\begin{array}{l}\text { Science and knowledge } \\
8\end{array}$ & 9 & 23 & 3 & 9 & 7 & 51 & 5.7 \\
\hline & $\begin{array}{l}\text { Rules, regulations and } \\
\text { acts }\end{array}$ & 9 & 13 & 1 & 9 & 13 & 45 & 5.1 \\
\hline & Total & 136 & 227 & 78 & 92 & 158 & 691 & 77.6 \\
\hline
\end{tabular}

All five schools' LL signs contain messages under the major themes. The top three themes consist of place direction or location (164 data or 18.4\%), morality and religion (120 data or 13.5\%) and environment and energy (101 data or $11.3 \%$ ), examples of which are following.

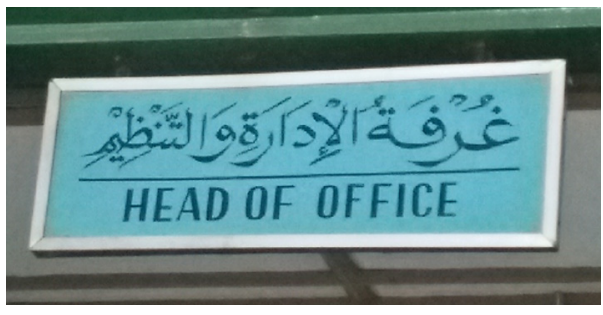

Figure 1. Arabic-English sign of principal's office (A2/227)

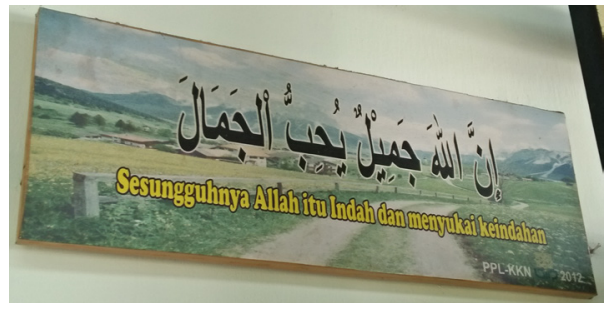

Figure 2. Arabic-Indonesian Islamic quote about beauty (A1/68) 


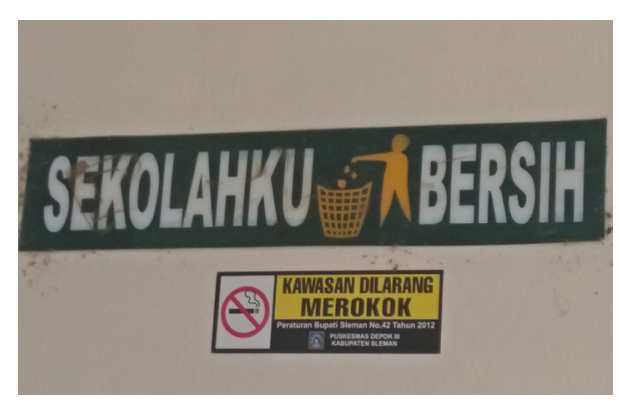

Figure 3. Declaring a clean environment (A3/526) and no smoking area $(\mathrm{A} 3 / 527)$

Figure 1 is a bilingual sign showing the location of "Head of Office". Examples of data with the same theme are a multilingual sign (A1/124) saying "Teacher's Office (Religious and Social)" in Arabic, English and French and sign A3/547 that refers to a classroom named R.P. Antasari, a national hero. Most of the signs with place direction or location are posted quite close to the referred places or locations.

Both Islamic schools have numerous morality and religion signs. Most signs are located in praying areas and classrooms. The sign in Figure 2-if written in Latin script would read Innallaaha jamiilu yuhibbuljamaal-means "Verily Allah is beautiful and loves beauty". An Indonesian sign in Datum A4/597 Belajar itu ibadah, meaning "Learning is a religious act", contains a moral or religious value but does not refer to any particular religion. An Arabic sign in Datum A5/744, saying Hasbunallah ni'mal maula wani'mal wakiil in Latin script, means "Allah (alone) is sufficient for us and He is the best disposer of affairs (for us)". This sign has a close relationship with Islam despite the fact that School A5 is not an Islamic school.

Signs with environment and energy theme are mostly in public spaces. Sign A3/526 in Figure 3 means "My school is clean", used to remind people to keep cleanliness. Sign A3/527 Kawasan Dilarang Merokok declares the area is smoking-free. Other data include A5/806 Jagalah kebersihan or "Let's keep (our school) clean" and A5/811 Matikan lampu apabila tidak digunakan, showing a request to save energy by switching off lamps when not in use.

The other five major themes are represented in Figures 4 to 8 respectively with school identity, school activities, how to comport oneself, science and knowledge, and rules, regulations and acts themes. 


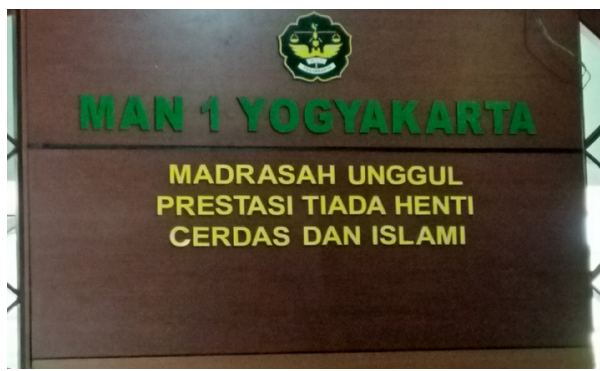

Figure 4. A school sign board (A1/32)

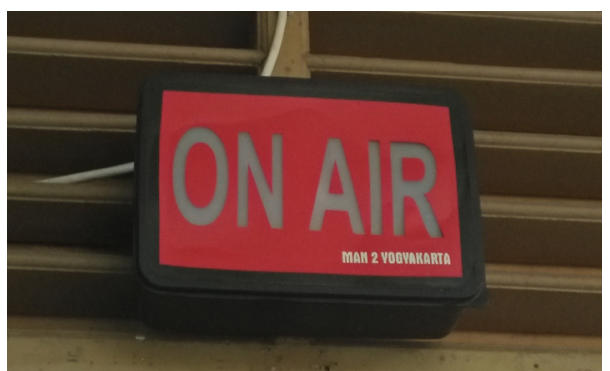

Figure 5. Announcement in front of broadcast room (A2/362)

A school front-side sign in Figure 4 indicates the school's name, school type and motto. Figure 5 illustrates an on-going broadcast activity.

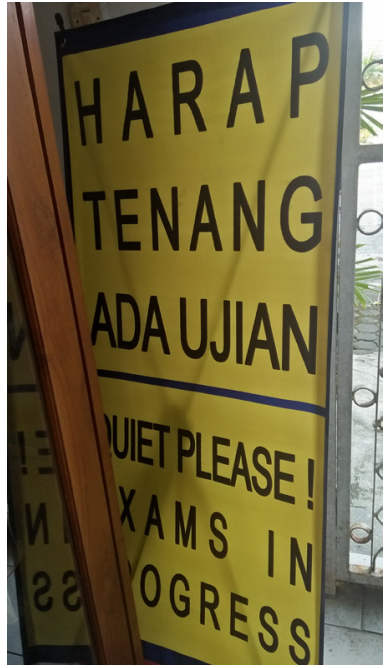

Figure 6. "Be quiet, please. Exams in progress" (A3/568)

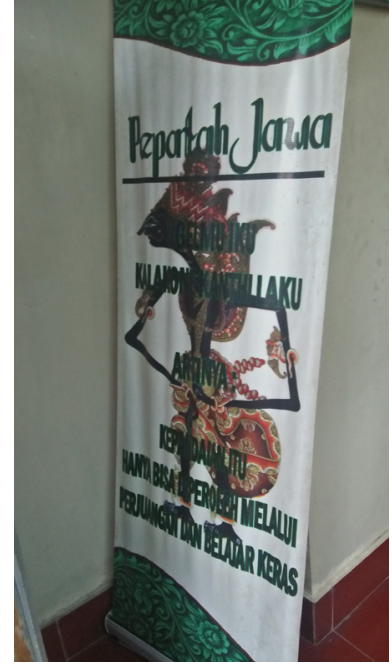

Figure 7. A Javanese proverb on knowledge and the Indonesian translation (A4/638)

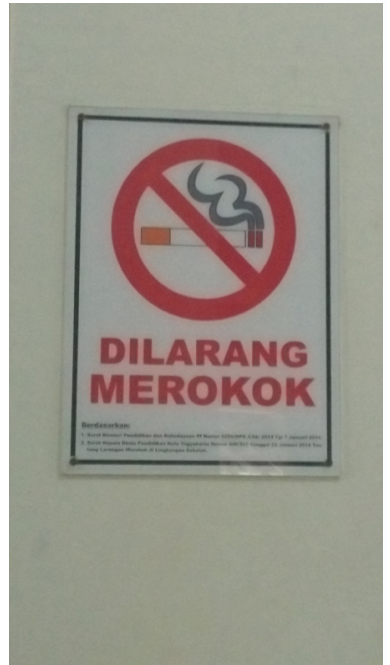

Figure 8. Smoking prohibition in Indonesian (A5/719)

Figure 6 depicts a temporary caution in the school's lobby. The JavaneseIndonesian sign (as shown in Figure 7) Pepatah Jawa. Ngelmu iku kelakon kanthi laku. Artinya: Kepandaian itu hanya bisa diperoleh melalui perjuangan dan belajar keras, meaning "We can acquire knowledge through struggle and hard study". was seen in a classroom. Figure 8 is a notice for not smoking around the school environment, placed on the lobby's side-wall. 
The distribution of the seven minor themes is presented in Table 4.

Table 4. Minor themes

\begin{tabular}{|c|c|c|c|c|c|c|c|c|}
\hline No. & Themes & $\begin{array}{l}\text { School } \\
\text { A1 }\end{array}$ & $\begin{array}{l}\text { School } \\
\text { A2 }\end{array}$ & $\begin{array}{c}\text { School } \\
\text { A3 }\end{array}$ & $\begin{array}{l}\text { School } \\
\text { A4 }\end{array}$ & $\begin{array}{l}\text { School } \\
\text { A5 }\end{array}$ & Total & Percentages \\
\hline 1 & Motivations & 16 & 16 & 5 & 7 & - & 44 & 4.9 \\
\hline 2 & Health & 3 & 11 & 13 & 6 & - & 33 & 3.7 \\
\hline 3 & $\begin{array}{l}\text { Equipment, products } \\
\text { or objects }\end{array}$ & 5 & 5 & 4 & 10 & 4 & 28 & 3.1 \\
\hline 4 & Security and safety & 1 & 5 & 2 & 6 & 8 & 22 & 2.5 \\
\hline 5 & Achievements & 13 & 4 & - & - & 3 & 20 & 2.3 \\
\hline 6 & $\begin{array}{l}\text { State symbols and } \\
\text { national figures }\end{array}$ & - & 1 & 15 & 4 & - & 20 & 2.3 \\
\hline 7 & Advertisement & 3 & - & - & 2 & 6 & 11 & 1.2 \\
\hline \multirow[t]{2}{*}{8} & Miscellany & 1 & 7 & 5 & 7 & 1 & 21 & 2.4 \\
\hline & Total & 42 & 49 & 44 & 42 & 22 & 199 & 22.4 \\
\hline
\end{tabular}

Two minor themes, namely equipment, products or objects and security and safety appeared in all five schools.

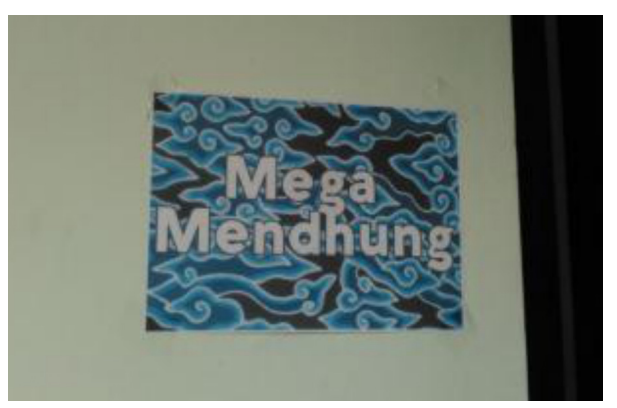

Figure 9. A popular batik motif (A1/178)

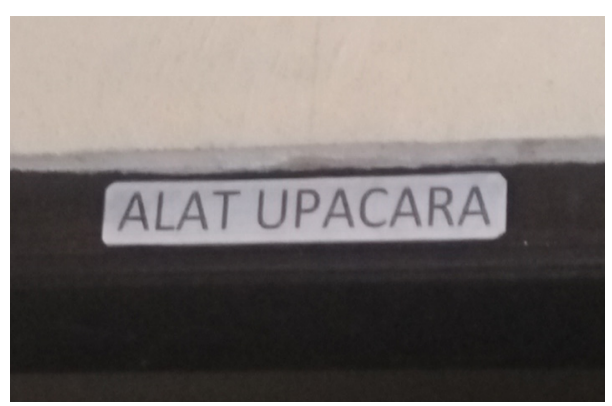

Figure 10. "Flag ceremony equipment" (A3/474)

Signs in Figures 9 to 10 respectively show a batik (traditional cloth) motif called mega mendhung, which is also found in Datum A4/666 and a room for storing flag ceremony equipment. Following signs in Figures 11 and 12 relate to schools' security and safety system. 


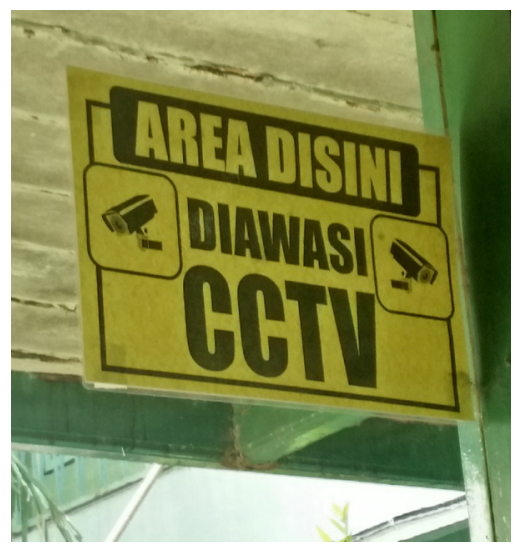

Figure 11. An area with CCTV (A2/270)

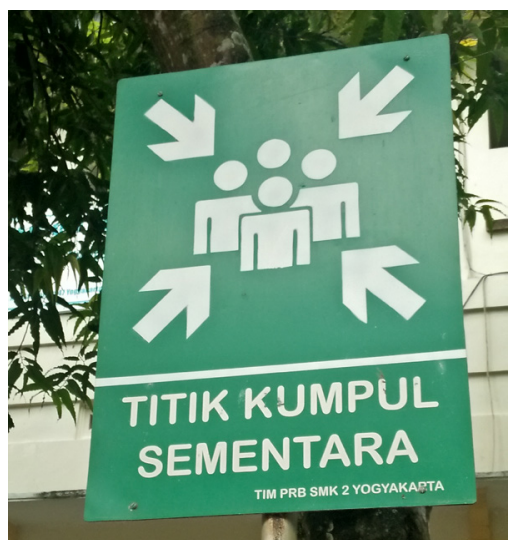

Figure 12. An assembly point (A5/864)

Signs with motivations and health themes are found in four schools, examples of which are following.

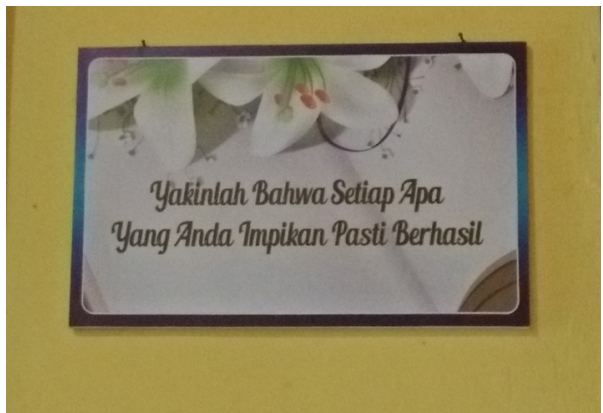

Figure 13. "Believe that your dream will come true" (A1/34)

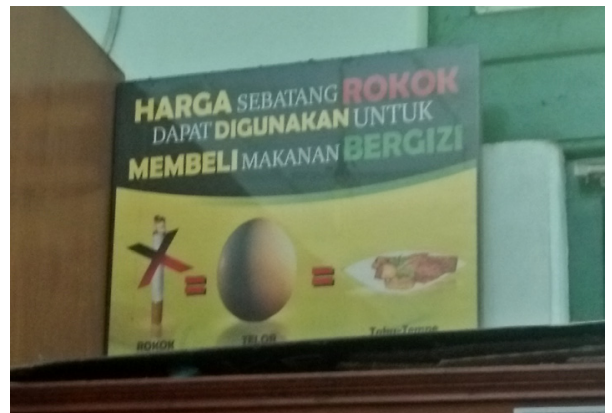

Figure 14. "Price of a cigarette equals that of healthy food"(A2/263)

Examples of signs with the last three minor themes: achievements, state symbols and national figures, and advertisements are as follows. 


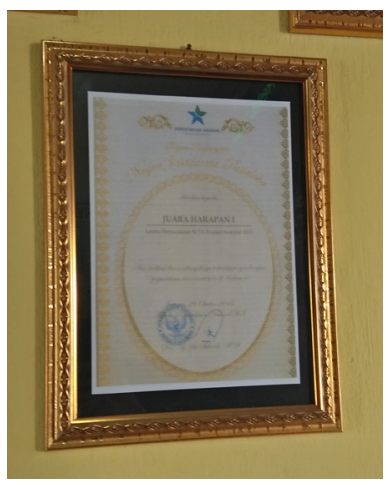

Figure 15. Certificate of achievement (A1/37)

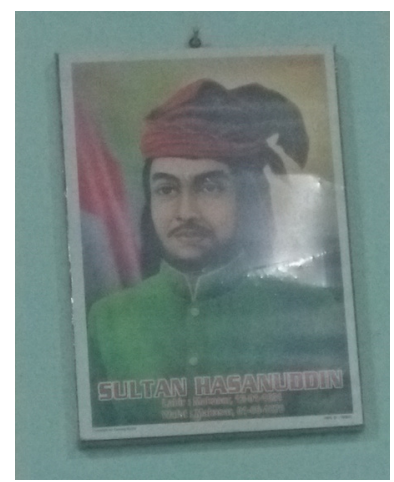

Figure 16. Sultan Hasanuddin, a national hero (A4/591)

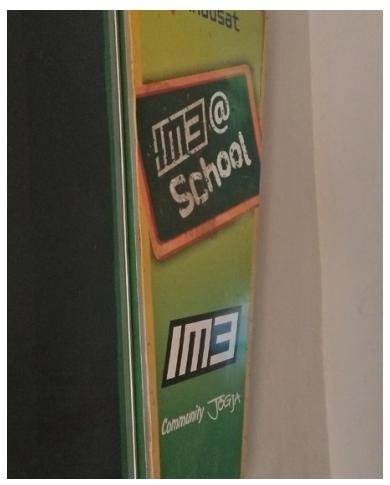

Figure 17.

Telecommunication advertisement (A4/669)

\section{Multimodality in the school LL}

The variety of modes discussed in this study includes language, image and colour. Table 5 illustrates the dominance of monolingual signs ( 750 or $84.3 \%$ ) over bi- and multilingual signs (140 in total or 15.7\%). Most monolingual signs (640 data) read in Indonesian, followed by English, Javanese and Arabic (Andriyanti, 2019). The distribution of each lingual pattern shows that monolingual signs have all themes, bilingual signs do not embody security and safety as well as state symbols and national figures themes and multilingual signs are related only to four themes: place direction or location, school identity and information, school activities and security and safety. The theme of state symbols and national figures is embodied only in monolingual Indonesian signs.

Table 5. Use of lingual patterns

\begin{tabular}{clcccc}
\hline No. & Themes & Monolingual & Bilingual & Multilingual & Total \\
\hline 1 & Place direction or location & 127 & 24 & 13 & 164 \\
2 & Morality and religion & 91 & 29 & - & 120 \\
3 & Environment and energy & 86 & 15 & - & 101 \\
4 & School identity and & 74 & 9 & 1 & 84 \\
& information & & & & \\
5 & Academic and non- & 58 & 10 & 1 & 69 \\
& academic activities & & & - & 57 \\
7 & How to comport oneself & 55 & 2 & - & 51 \\
\hline
\end{tabular}


Table 5. (Continued)

\begin{tabular}{|c|c|c|c|c|c|}
\hline No. & Themes & Monolingual & Bilingual & Multilingual & Total \\
\hline 8 & Rules, regulations and acts & 41 & 4 & - & 45 \\
\hline 9 & Motivations & 38 & 6 & - & 44 \\
\hline 10 & Health & 24 & 9 & - & 33 \\
\hline 11 & $\begin{array}{l}\text { Equipment, products or } \\
\text { objects }\end{array}$ & 27 & 1 & - & 28 \\
\hline 12 & Security and safety & 21 & - & 1 & 22 \\
\hline 13 & Achievements & 19 & 1 & - & 20 \\
\hline 14 & $\begin{array}{l}\text { State symbols and national } \\
\text { figures }\end{array}$ & 20 & - & - & 20 \\
\hline 15 & Advertisement & 8 & 3 & - & 11 \\
\hline \multirow[t]{2}{*}{16} & Miscellany & 17 & 1 & 3 & 21 \\
\hline & Total & $750(84.3 \%)$ & $121(13.6 \%)$ & $19(2.1 \%)$ & $890(100 \%)$ \\
\hline
\end{tabular}

The different languages in the $140 \mathrm{bi}$ - and multilingual signs contribute to the meanings in three ways (as shown in Table 6). First, they convey the same meaning. Second, the second or the other languages have the same meaning as the first language but also give any additional meanings. Third, the languages convey different meanings. The ratio between meaning sameness and differences in this case is almost equal, represented by 66 and 74 data.

Table 6. Meanings through different languages

\begin{tabular}{llcccc}
\hline & & \multicolumn{3}{c}{ Contents in bi-/multilingual texts } & \\
\cline { 3 - 5 } No. & Themes & Same & $\begin{array}{c}\text { Same with } \\
\text { addition }\end{array}$ & Different & Total \\
\hline 1 & Place direction or location & 23 & 3 & 11 & 37 \\
2 & Morality and religion & 9 & 13 & 7 & 29 \\
3 & Environment and energy & 3 & 1 & 11 & 15 \\
4 & School identity and information & - & - & 10 & 10 \\
5 & Academic and non-academic activities & 1 & - & 10 & 11 \\
6 & How to comport oneself & 2 & - & - & 2 \\
7 & Science and knowledge & 4 & 1 & 2 & 7 \\
8 & Rules, regulations and acts & - & - & 4 & 4 \\
9 & Motivations & - & 3 & 3 & 6 \\
10 & Health & - & - & 9 & 9 \\
\hline
\end{tabular}


Table 6. (Continued)

\begin{tabular}{llcccc}
\hline & & \multicolumn{3}{c}{ Contents in bi-/multilingual texts } & \\
\cline { 3 - 5 } No. & Themes & Same & $\begin{array}{c}\text { Same with } \\
\text { addition }\end{array}$ & Different & Total \\
\hline 11 & Equipment, products or objects & - & - & 1 & 1 \\
12 & Security and safety & - & - & 1 & 1 \\
13 & Achievements & - & - & 1 & 1 \\
14 & Advertisement & - & - & 3 & 3 \\
15 & Miscellany & 3 & - & 1 & 4 \\
\hline & Total & 45 & 21 & 74 & 140 \\
\hline
\end{tabular}

Figures 18 to 20 show each type of meanings.

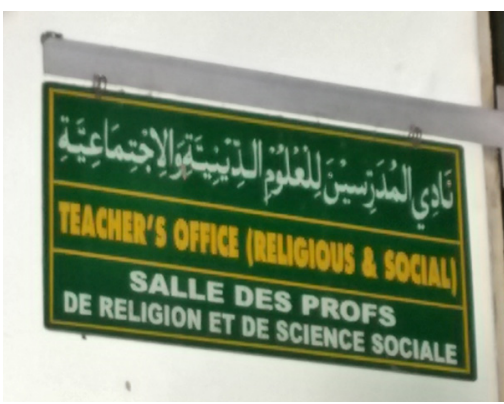

Figure 18. The same meaning through three languages (A1/124)

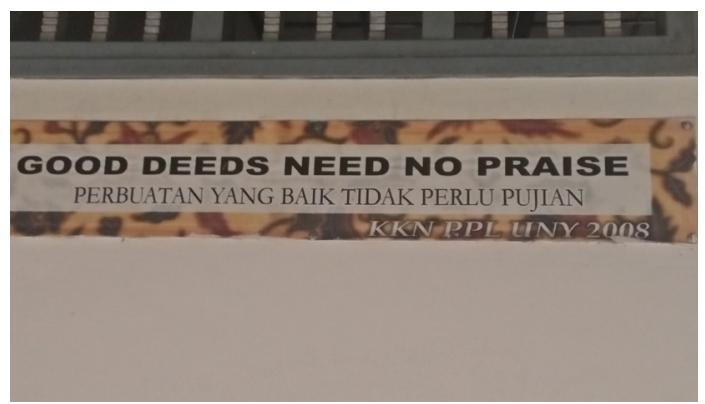

Figure 19. An English proverb with Indonesian translation, added with the sign maker's identity (A5/820)

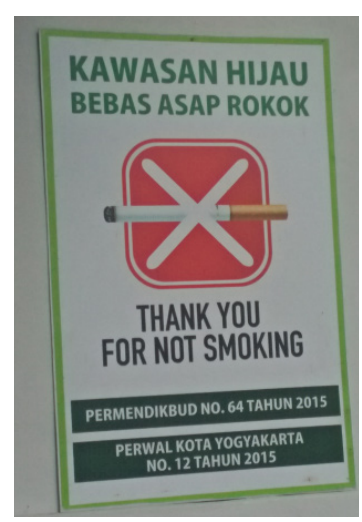

Figure 20. Different meanings through Indonesian and English (A4/587) 
Table 7 illustrates the common use of images in the school LL (385 data or $43 \%$ ). Environment and energy theme has the highest frequency (59 data), science and knowledge theme ranks second (39 occurrences) and school identity and information ranks third (37 occurrences). Almost similar in number are place direction or location (35 data), morality and religion (35 data) and school activities (34 data).

Table 7. Use of language and image

\begin{tabular}{llccc}
\hline No. & Themes & Language & $\begin{array}{c}\text { Language } \\
\text { and image }\end{array}$ & Total \\
\hline 1 & Place direction or location & 129 & 35 & 164 \\
2 & Morality and religion & 85 & 35 & 120 \\
3 & Environment and energy & 42 & 59 & 101 \\
4 & School identity and information & 47 & 37 & 84 \\
5 & Academic and non-academic activities & 35 & 34 & 69 \\
6 & How to comport oneself & 50 & 7 & 57 \\
7 & Science and knowledge & 12 & 39 & 51 \\
8 & Rules, regulations and acts & 27 & 18 & 45 \\
9 & Motivations & 23 & 21 & 44 \\
10 & Health & 3 & 30 & 33 \\
11 & Equipment, products or objects & 17 & 10 & 27 \\
12 & Security and safety & 9 & 14 & 23 \\
13 & Achievements & 5 & 15 & 20 \\
14 & State symbols and national figures & 8 & 12 & 20 \\
15 & Advertisement & 5 & 6 & 11 \\
16 & Miscellany & 8 & 13 & 21 \\
\hline & Total & $505(57 \%)$ & $385(43 \%)$ & $890(100 \%)$ \\
\hline
\end{tabular}


The use of images is exemplified in Figures 21 to 23.

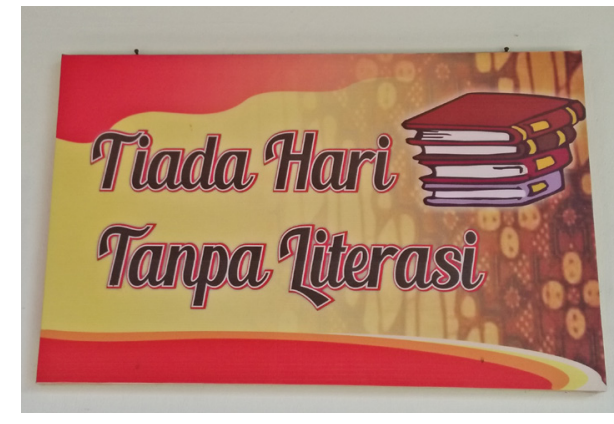

Figure 21. A book picture in "No days without literacy" (A1/111)

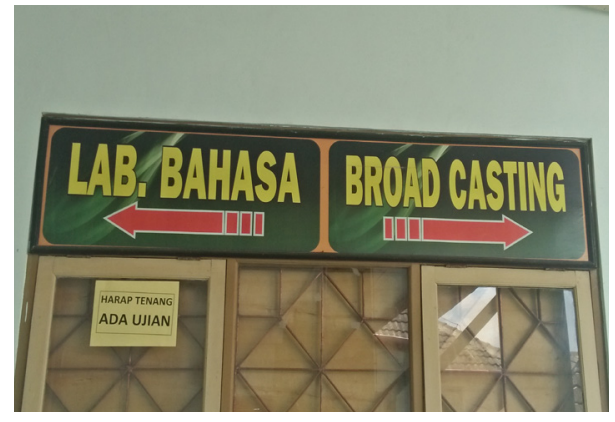

Figure 22. A bilingual sign with opposite arrows directing to two different places (A2/359)

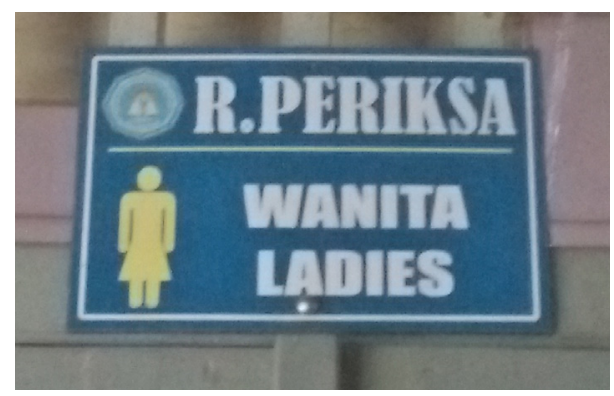

Figure 23. Medical ward for females (A5/817)

In addition to the verbal text and image, colour is also saliently used in the signs (as shown in Table 8). Soft colours are dominant, almost a half in number. Black and or white and bright or contrastive colours are almost equal in number (more than 20\%) while gold colour has the smallest percentage $(1.4 \%)$ and is present only in four themes. The soft and black and or white colours are used in all themes. Bright and contrastive colours are not used in signs with state symbols and national figures. 
Table 8. Use of colours

\begin{tabular}{rlccccc}
\hline No. & Themes & $\begin{array}{c}\text { Black and } \\
\text { or white }\end{array}$ & Soft & $\begin{array}{c}\text { Bright or } \\
\text { contrastive }\end{array}$ & Gold & Total \\
\hline 1 & Place direction or location & 72 & 32 & 59 & 1 & 164 \\
2 & Morality and religion & 13 & 77 & 27 & 3 & 120 \\
3 & Environment and energy & 15 & 58 & 28 & - & 101 \\
4 & School identity and information & 13 & 42 & 22 & 7 & 84 \\
5 & Academic and non-academic & 23 & 34 & 12 & - & 69 \\
& activities & & & & & \\
6 & How to comport oneself & 21 & 21 & 15 & - & 57 \\
7 & Science and knowledge & 2 & 44 & 5 & - & 51 \\
8 & Rules, regulations and acts & 11 & 15 & 19 & - & 45 \\
9 & Motivations & 3 & 28 & 13 & - & 44 \\
10 & Health & 1 & 30 & 2 & - & 33 \\
11 & Equipment, products or objects & 9 & 17 & 2 & - & 28 \\
12 & Security and safety & 5 & 6 & 11 & - & 22 \\
13 & Achievements & 9 & 8 & 2 & 1 & 20 \\
14 & State symbols and national & 6 & 14 & - & - & 20 \\
& figures & & & & & 11 \\
15 & Advertisement & 1 & 4 & 6 & - & 21 \\
16 & Miscellany & 2 & 14 & 5 & - & 890 \\
\hline & Total & 206 & 444 & 228 & 12 \\
& & $(23.1 \%)$ & $(49.9 \%)$ & $(25.6 \%)$ & $(1.4 \%)$ & $(100 \%)$ \\
\hline
\end{tabular}

The varied use of colours is exemplified in Figures 24 to 26.

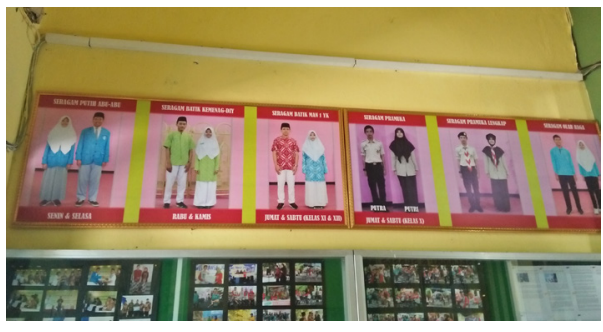

Figure 24. Colours of student uniforms (A1/33)

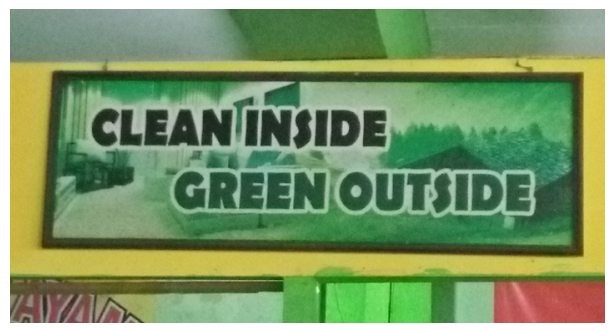

Figure 25. A greenish sign in the "go green" school (A2/210) 


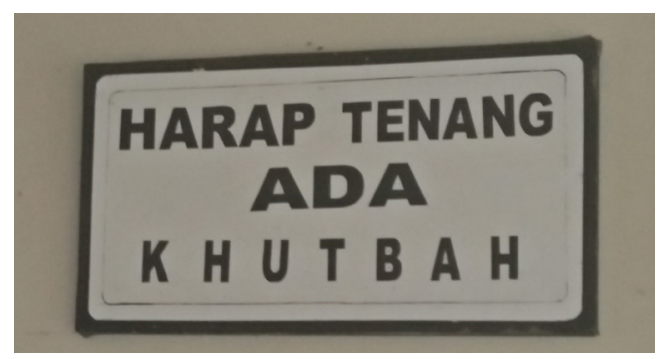

Figure 26. Black on white sign requesting people to keep silent during Friday sermon (A5/767)

\section{Discussion}

The discussion of the signs' meanings or messages under the emerging themes is mainly based on indexicality and their importance for education and school environment. The construction of the social meanings is connected to the social functions of the three main modes: language, image and colour in communication. Whether these different modes are iconic or symbolic are discussed in relation to their contribution to the social construction of reality. All of the interpretation of the signage is based on the three geosemiotic systems: interaction order, visual semiotics and place semiotics (Scollon and Scollon 2003).

\section{The school LL's themes and social meanings}

The highest frequency of place direction or location theme indicates that most of the school signage closely relates to the traditional definition of LL, in which road signs, street names, shop signs and other signs in buildings are essential components (Landry and Bourhis 1997). Signs having this theme are public and are intended for all people, especially those who are not familiar with places at a particular school. For school members, the existence of these signs is pivotal since school buildings commonly have a large number of rooms. Most signs are verbal without images because they refer to places which are located nearby. For instance, Figures 1 and 18 refer alternately to principal' and teachers' rooms and the place signs are put above the doors. All of the signs with this theme are indexical at least in two ways. First, they are located quite close to places they refer. Second, some of them use indexical languages or pictures such as an arrow, which is a faster way of saying "it is the way of going to" the places (as shown in Figure 22). The pervasive posting of such signs indicates that they serve as public notices. Especially to school outsiders, these public signs are very important for them to familiarise with the schools and their surroundings. In term of social interaction, people do not need to ask others 
when they want to find places or locations because the signs already inform them. The closeness of the signs and their referents helps the readers to find the places and locations easily.

Signs with morality and religion theme were found not only in the two Islamic schools but also in the other three schools, implying that all school LL makers emphasise the importance of instilling moral and religious values in education. Through the signs the makers remind the readers, especially school members, of moral or religious principles and practices. The signs perform the main function of school to educate or to transform moral, social and religious values. The sign indexicality can be linked commonly to areas or places for religious activities and classrooms. The Arabic signs (e.g., as shown in Figure 2) are found pervasive in both Islamic schools. An Indonesian sign which means "Learning is a religious act" (A4/597) was posted in a classroom and therefore indexical. Another example is a short Islamic prayer in Arabic (A1/124) posted near a mirror, reminding the mirror user to check his appearance.

Environment and energy theme is the third biggest concern for LL school makers. This theme is embodied mostly in messages related to cleanliness (as shown in Figures 3 and 25) and others about tree-planting (e.g., A2/305), global warming issues (e.g., A2/308), the importance of tree-planting to anticipate global warming (e.g., A4/621) and energy saving (e.g., A4/607, A4/625, A5/811). The signs' indexicality is obvious in cleanliness and energy saving themes. Cleanliness signs are commonly found in the school playground and open areas, especially near dustbins; energy saving signs near power outlets and lamp switches. In the case of signs that appeal for planting trees to anticipate global warming, the indexicality is relevant to any schools holding "go green" slogans, such as School A2. Asking, requesting or appealing through the signs is considered important to remind the readers of this significant issue and the schools' commitment to the environment.

Signs with school identity theme are first and foremost placed in school front or outer parts, informing the schools' existence publicly. The signs for school activities are indexical not only based on space but also time. For example, a sign in front of a broadcast room (as shown in Figure 5) reads ON because a broadcast activity is going on at the time being and will turn OFF when the activity is over. Similar temporary signs relate to activities during the fasting month. Rather differently, the permanent sign A1/21 informs when extracurricular activities should finish. A few signs with how to comport oneself are also temporary (e.g., as shown in Figure 6) but most are permanent, related to messages for students or other school members to have good behaviour 
and manner. Many signs with knowledge and science theme are found inside classrooms (e.g., as shown in Figures 7 and 21). This indexicality is quite relevant to school as an academic environment and learning place. Rules, regulation and act theme is inseparable from school as a formal institution. This theme is embodied in numerous signs with messages related to smoking prohibition at school and other government institution (e.g., as shown in Figure 8), supported by valid regulation or acts; also to uniforms (as shown in Figure 24).

Signs' indexicality is also found in minor themes. Signs showing equipment, products and objects are in close proximity to the referents (e.g, as shown in Figures 9 and 10). Other signs of this type read, for instance, "suggestion box" (A1/107), "sound-system room" (A5/754) and "Javanese names of batik motifs". Security and safety theme is indexical to place (e.g., as shown in Figures 11 and 12), which includes messages related to CCTV monitoring and assembly point in case of existing danger. It might also be embodied in indexical signs of evacuation having arrow images directing to gates or other exits. Motivation signs are mostly found in classrooms (e.g., as shown in Figure 13). The messages are related to learning and success and therefore addressed to students. Health signs shown in Figures 14 and 23 are located in school medical wards. Achievement signs are both temporary and permanent. The former is banners to congratulate the achievers after particular events and the latter is certificates hung on the schools' inside wall or room wall. Advertisement signs are found in front-part public spaces and seemingly relate to sponsorship and to products relevant to students or young people, such as branded eraser, international and local drinks and mobile cards. The placement of the advertisements gives a hint that schools' permission is restricted so that the advertisers cannot go further inside the school buildings. The last minor theme of state symbols and national figures can be connected to the government requirement for institutions to have the national emblem Garuda Pancasila and the pictures of the current president and vice-president while having those of other figures such as national heroes is not mandatory.

\section{The contribution of multimodality to the school LL social meanings}

The use of various modes relates to different functions in a sign meaningmaking. For example, a written text conveys something which is hard to illustrate, an image presents a picture that can be read faster than words and a colour highlights and frames the messages (Kress 2010). Following is a discussion on the use of three main modes in the studied school LL. 


\section{Language}

The use of one or more languages is significant to both communication and representation. The data indicate that the monolingual signs in Indonesian, Javanese, English, Arabic or French communicate specific information or ideas related to all emerging themes. They also represent the social reality, such as the language status, the culture inherent in the language and the facts about the makers who use the language in the signs (Andriyanti 2019). The choice of languages in monolingual signs relates to language subjects learnt at senior high schools in Yogyakarta. The use of Arabic in monolingual signs, especially at the Islamic schools, can be interpreted as representing the schools' identity and that in a number of morality and religion signs are symbolical with regard to their Islamic contents.

The languages in some bilingual and multilingual signs were found to convey the same meaning without or with additional meaning and in some others deliver totally different meanings (as shown in Figure 20). Different languages with the same meaning are usually in forms of short expressions having place direction (e.g., as shown in Figures 1 and 18) and religion and moral values themes (e.g., as shown in Figure 2). One of the languages used is either Indonesian, English or Arabic, which is in the first or second mentions. The seemingly redundant meaning in the bi-/multilingual signs represents the language diversity in the school LL rather than language inefficiency. Indonesian language is the most understood language. The short English expressions are common as well. In term of communication, both languages perform this function. This phenomenon might be well regarded as language symbolism through which schools introduce the existing languages at place. In the use of Arabic as the first language written on top of the sign, the second language contains the translation. Since Arabic is understood by relatively a small group of people, the same meaning conveyed through the second-ordered language (commonly Indonesian) performs the function to communicate rather than as a symbol. As for Arabic, the social meaning is twofold. It is symbolic in relation to Islamic identity and educational to make students understand well the meanings borne by the Arabic texts. Additional meaning often relates to outsiders as the sign maker, as exemplified in Figure 19.

The use of different languages with different meanings commonly appears as code-mixing, which is a common multilingual phenomenon (e.g., as shown in Figure 20). Generally, insertion of non-Indonesian languages is done in the 
pervasive use of Indonesian in most of the signage with purposes of catching attention, showing the sign maker's identity or applying common borrowed foreign terms.

\section{Image}

Not everything that can be realised in language can also be realised by means of images or vice versa. In school LL, images are used mostly to bear their specific function as text that can be comprehended faster even from a distance or to give additional information. Most of the existing images are iconic or figural rather than abstract.

A prominent example is the existence of images accompanying verbal smoking prohibition and other similar bans. This kind of images is globally acknowledged. A no smoking image is usually iconic, having a picture of lit cigarette with smoke in red circle with line through. The verbal texts might express various messages, which in English means "no smoking area" or "smoking is prohibited", which are often added with regulations related to the ban. With or without the verbal text, this image might stand alone to communicate the message. Images of similar kind are positioned above, to the left of or in the middle of the verbal texts, becoming objects to be noticed earlier or understood faster than the verbal texts.

Another example is male or female figures, commonly put below the word "toilet" (A5/729). The semiotic placement indicates toilet location as general information and the figures as specific information. The image is significant to anticipate people's entering a wrong place not for their gender because a toilet relates to privacy. The female image in Figure 23 functions similarly but is located in a school medical ward.

Most of the signs under environment and energy theme tend to be iconic. Cleanliness signs are often accompanied by icons of "a person puts rubbish in a dust bin" (e.g., as shown in Figure 3). Electricity saving signs have pictures of lamps and switches. The "go green slogans" go with pictures of trees. These images clearly support the messages. On one hand, the images are redundant with regard to contents. On the other hand, their existence is visually appealing and helps the target readers get the message more easily. The person drawing, not the real-person image, in environment as well as direction or location signs represents people in general. 
However, images might also become the given components, which are explained by verbal text. For example, signs of the Indonesian hero figures are always accompanied with verbal texts giving new information about their names, without which the figures remain foreigners to the viewers (e.g., as shown in Figure 16). Similarly, signs with batik motifs are accompanied by the motif names, without which people will just know the motifs as batik in general. The images in these examples are entities to be labelled and introduced especially to students so that respectively they will be familiar with the great people in the country's history and with the local heritage.

Some of the images are symbolic, as shown in Figure 21, wherein the books symbolise literacy. The picture of Krishna (as shown in Figure 7), a prominent figure in Mahabharata story, symbolises wisdom, which is relevant to the goal of pursuing knowledge. The various batik motifs are symbols of culture preservation, committed by a number of schools in Yogyakarta, which is the centre of Javanese culture.

The use of images to accompany languages or vice versa in this study is relatively high $(43 \%)$, implying their perceived significant existence to convey messages. The meaning potentials of the two modes are not fully conflated because they bear their own specific functions (Kress and van Leeuwen 2006) and in the conflation both semiotic resources interact to produce meaning in a way that cannot be realised by any single mode alone (Lemke 2002).

\section{Colour}

Different types of colours contribute to making different meanings and give different impressions. Page, Thorsteinsson and Ha (2012) and Maden, Hewett and Roth (2000) show evidence of the effects of colours on marketing communication and differently Kurt and Osueke (2014) on college students' moods. This present study reveals that the use of colours in the school LL is iconic as well as symbolic and affects the meaning-making in numerous ways.

The iconic colours are evidently found, for example, in the colours of students' uniforms in the images accompanying signs with rules, regulation and acts theme (as shown in Figure 25). Rather than describing in words about which coloured-uniforms have to be worn on particular days per week, the colours of the uniforms themselves say exactly about the uniform rules and make the rules easy to remember. Another example is the use of greenish colours to support environment (and energy) theme, which significantly contributes to the theme- 
based meaning-making because indisputably the colour is iconic to leaves and plants and represents environmental awareness in many cultures. Most of signs promoting "green school and environment" are also coloured green (e.g., as shown in Figures 3, 20 and 25).

The symbolic colours are related to the universally acknowledged meanings as well as the local cultural values and acceptance. For example, as green is the sacred colour for Islam (Bortoli and Maroto 2008; Wright 2008), the school buildings in general and the signs showing places in the two Islamic schools are dominant with the green colour. Historically, colour symbolism is closely related to the psychological properties of colours because they often coincide (Wright 2008). The dominance of soft colours at the school LL in general might bring effects of calmness and tranquillity, which are perceived as supportive to learning environments. The use of black and or white colours is often connected to seriousness, neutrality and formality (e.g., as shown in Figure 25). Black and or white colours share some similar representation: clarity, seriousness and sophistication and are often combined (Wright 2008). The use of these two universal colours that exist in all languages (Bortoli and Maroto 2008), either separately or in combination, does not fail the sense emphasised by the sign makers about school as a formal and serious place. Bright or contrastive colours catch viewers' eyes, signalling that signs in this sort of colours need to be paid immediate attention. Prohibitions, instructions and cautions in environment and energy theme, health theme, as well as safety and security theme are mostly found in bright colours such as red and yellow or combination between them with white and black. Red is powerful and grabs first attention while yellow is the strongest and stimulating colour (Page, Thorsteinsson and Ha 2012; Wright 2008). The colour (yellowish or brownish) gold is often associated with wealth, glory, success and achievement since gold is a precious metal which is highly valued. Least frequently found, this colour is used to show school identities signs (e.g, as shown in Figure 4) and achievement-themed signs (e.g., as shown in Figure 15).

The colour choice in the school LL, which is dominated by soft colours in almost a half number of signs, matches needed peaceful atmosphere that will support learning. Formality colour of black and white letters in the signage is pervasive enough and most bright or contrastive signs' colours function to capture readers' immediate attention with regard to safety, urgency and immediate importance. That, "the significance of colour to convey meaning is evident" (Maden, Hewett and Roth 2000) is apparent in the school LL. 


\section{Conclusion}

As Gorter (2006b) states, the multimodal social semiotics is a useful approach to understand the sociocultural contexts of linguistic signs, which commonly appear with images and are located in a particular place.

The major and minor themes found in the studied school LL show which messages are prioritised to be delivered to the addressees. To make effective comunications, the use of Indonesian and English short expressions is dominant. In general, moral and religious values are more emphasised than knowledge and science. A condusive environment to support learning processes is important, evidenced through environment and energy saving signs as the third rank major theme and the dominant use of soft and harmonious colours. The signs in the images are not only indexical but also iconic and symbolical. Both images and colours contribute to the social meaning-making in the communicative processes and add the visual appeal. The signs are both for public and school members, especially students. The sign makers are mostly internal and a few external parties.

Further studies related to meaningfulness of school LL, LL signage as educational resources or school members' language awareness of those in school LL are suggested. The first type of studies can be conducted, for example, through investigation of people's perception and opinions towards any existing LL. The second might be done with regard to the language and cultural aspects. The third might be aimed at, among others, evaluating if people in the school environment have sufficient knowledge about the used languages in their school LL.

\section{Acknowledgments}

I am indebted to the Institute for Research and Community Services (Lembaga Penelitian dan Pengabdian pada Masyarakat, LPPM) of Universitas Negeri Yogyakarta for funding this research (Grant Number: 05/Penelitian/Pasca Doktor/UN 34.21/2018). My thanks go to Retna Ikawati and Nadia Khumairo Ma'shumah for assisting me during the fieldwork. I also thank Budi Hermawan of Universitas Pendidikan Indonesia for his critical review during the process of my writing the manuscript. Last, I highly appreciate the five senior high schools for participating in this study. 


\section{References}

Act No. 20. 2003. Undang-undang Republik Indonesia nomor 20 tahun 2003 tentang sistem pendidikan nasional (Act of the Republic of Indonesia number 202003 on national education system). Jakarta: Ministry of National Education.

Act No. 24. 2009. Undang-undang Republik Indonesia nomor 24 tahun 2009 tentang bendera, bahasa dan lambang negara, serta lagu kebangsaan (Act of the Republic of Indonesia number 242009 on nation's flag, languages, emblem, and anthem). Jakarta: Ministry of Law and Human Right.

Andriyanti, E. 2019. Linguistic landscape at Yogyakarta's senior high schools in multilingual context: Patterns and representation. Indonesian Journal of Applied Linguistics 9(1): 85-97. https://doi.org/10.17509/ijal.v9i1.13841

Backhaus, P. 2006. Multilingualism in Tokyo: A look into the linguistic landscape. In Linguistic landscape: A new approach to multilingualism, ed. D. Gorter, 52-66. Clevedon, UK: Multilingual Matters. https://doi.org/10.1080/14790710608668385

Ben-Rafael, E., Shohamy, E., Amara, M.H. and Trumper-Hecht, N. 2006. Linguistic landscape as symbolic construction of the public space: The case of Israel. In Linguistic landscape: A new approach to multilingualism, ed. D. Gorter, 7-30. Clevedon, UK: Multilingual Matters. https://doi.org/10.1080/14790710608668383

Bezemer, J. and Jewitt, C. 2010. Multimodal analysis: Key issues. In Research methods in linguistics, ed. L. Litosseliti, 180-197. London: Continuum.

Bortoli, M.D. and Maroto, J. 2008. Colours across cultures: Translating colours in interactive marketing communications. Retrieved from http://www. globalpropaganda.fresa.net/articles/TranslatingColours.pdf (accessed 30 November 2019).

Brown, K.D. 2012. The linguistic landscape of educational spaces: Language revitalization and schools in Southeastern Estonia. In Minority languages in the linguistic landscape, eds. D. Gorter, L.V. Mensel and H.F. Marten, 281-298. Hampshire, UK: Palgrave Macmillan. https://doi.org/10.1057/9780230360235_16

Cenoz, J. and Gorter, D. 2008. The linguistic landscape as an additional source of input in second language acquisition. IRAL 46: 267-287. https://doi.org/10.1515/ IRAL.2008.012

Chandler, D. 1994. Semiotics for beginners. Retrieved from http://visual-memory.co.uk/ daniel/Documents/S4B/ (accessed 30 July 2018). 2007. Semiotics the basics. 2nd Ed. London: Routledge.

Da Silva, A.M. 2014. Upon the prevalence of English on billboard advertisements: Analyzing the role of English in Indonesian contexts. TEFLIN Journal 25(1): 33-61.

Decree No. 207. 2014. Keputusan Menteri Agama Republik Indonesia nomor 207 tahun 2014 tentang kurikulum madrasah (Ministry of Religious Affairs' decree number 2072014 on curriculum of Islamic schools). Jakarta: Ministry of Religious Affairs.

Fakhiroh, Z. and Rohmah, Z. 2018. Linguistic landscape in Sidoarjo city. NOBEL Journal of Literature and Language Teaching 9(2): 96-116. https://doi.org/10 .15642/NOBEL.2018.9.2.96-116 
Gorter, D. 2006a. Introduction: The study of the linguistic landscape as a new approach to multilingualism. In Linguistic landscape: A new approach to multilingualism, ed. D. Gorter, 7-6. Clevedon, UK: Multilingual Matters. https://doi.org/10.1080/ 14790710608668382

2006b. Further possibilities for linguistic landscape research. In Linguistic landscape: A new approach to multilingualism, ed. D. Gorter, 81-89. Clevedon, UK: Multilingual Matters. https://doi.org/10.21832/9781853599170-006

. 2013. Linguistic landscapes in a multilingual world. Annual Review of Applied Linguistics 13: 190-212. https://doi.org/10.1017/S0267190513000020

Hanauer, D.I. 2010. Laboratory identity: A linguistic landscape analysis of personalized space within a microbiology laboratory. Critical Inquiry of Language Studies 7(23): 1-21. https://doi.org/10.1080/15427581003757442

Harbon, L. and Halimi, S.S. 2019. A “disjunct” in the linguistic landscape: Messages about food and nutrition in Indonesian school environment. Indonesian Journal of Applied Linguistics 8(3): 620-631. https://doi.org/10.17509/ijal.v8i3.15263

Hewitt-Bradshaw, I. 2014. Linguistic landscape as a language learning and literacy resource in Carribean Creole contexts. Carribean Curriculum 22: 157-173.

Hoopes, J., ed. 1991. Peirce on signs: Writing on semiotics by Charles Sanders Peirce. Chapel Hill, NC: The University of North Carolina Press.

Huebner, T. 2006. Bangkok's linguistic landscape: environmental print, codemixing and language change. In Linguistic landscape: A new approach to multilingualism, ed. D. Gorter, 31-51. Clevedon, UK: Multilingual Matters. https://doi.org/ $10.1080 / 14790710608668384$

Kallen, J.L. 2010. Changing landscapes: Language space and policy in the Dublin linguistic landscape. In Semiotic Landscapes: Language, Image, Space, eds. A. Jaworsky and C. Thurlow, 41-58. London: Continuum.

Keane, W. 2003. Semiotics and the social analysis of material things. Language and Communication 23: 409-425. https://doi.org/10.1016/S0271-5309(03)00010-7

Kress, G. 2010. Multimodality: A social semiotic approach to contemporary communication. London: Routledge.

Kress, G. and van Leeuwen, T. 2006. Reading images. The grammar of visual design. London: Routledge.

Kurt, S. and Osueke, K.K. 2014. The effects of color on the moods of college students. SAGE Open 4(1): 1-12. https://doi.org/10.1177/2158244014525423

Landry, R. and Bourhis, R.Y. 1997. Linguistic landscape and ethnolinguistic vitality: An empirical study. Journal of Language and Social Psychology 16: 23-49. https://doi.org/10.1177/0261927X970161002

Lemke, J.L. 2002. Travels in hypermodality. Visual Communication 1(3): 299-325. https://doi.org/10.1177/147035720200100303

Lotherington, H. 2013. Creating third spaces in the linguistically heterogeneous classroom for the advancement of plurilingualism. TESOL Quarterly 47(3): 619625. https://doi.org/10.1002/tesq. 117

Maden, T.J., Hewett, K. and Roth, M.S. 2000. Managing images in different cultures: A cross-national study of color meanings and preferences. Journal of International Marketing 8(4): 90-107. https://doi.org/10.1509/jimk.8.4.90.19795 
Malinowski, D. 2010. Showing seeing in the Korean linguistic cityscape. In Linguistic landscape in the city, eds. E. Shohamy, E. Ben-Rafael and M. Barni, 199-215. Bristol: Multilingual Matters. https://doi.org/10.21832/9781847692993-013

Marten, H.F, Mensel, L.V and Gorter, D. 2012. Studying minority languages in the linguistic landscapes. In Minority languages in the linguistic landscape, eds. D. Gorter, L.V. Mensel and H.F. Marten, 1-15. Hampshire: Palgrave Macmillan. https://doi.org/10.1057/9780230360235_1

Page, T., Thorsteinsson, G. and Ha, J.G. 2012. Using colours to alter consumer behaviour and product success. International Journal of Contents 8(1): 69-73. https://doi.org/10.5392/IJoC.2012.8.1.069

Patton, M.Q. 1999. Enhancing the quality and credibility of qualitative analysis. HSR: Health Services Research 34(5) Part II: 1189-1208.

Periasamy, M.S., Gruba, P. and Subramaniam, G. 2015. A multimodal literary analysis of a television commercial. 3L: Language, Linguistics, Literature ${ }^{\circledR}$ The Southeast Asian Journal of English Language Studies 21(3): 151-164.

Przymus, S.D. and Kohler, A.T. 2018. SIGNS: Uncovering the mechanisms by which messages in the linguistic landscape influence language/race ideologies and educational opportunities; Linguistics and education. Linguistics and Education 44: 58-68. https://doi.org/10.1016/j.linged.2017.10.002

Sayer, P. 2010. Using the linguistic landscape as a pedagogical resource. ELT Journal 64(2): 143-154. https://doi.org/10.1093/elt/ccp051

Scollon, R. and Scollon, S.W. 2003. Discourses in place: Language in the material world. London: Routledge.

Wright, A. 2008. Colour psychology. Retrieved from http://www.colour-affects.co.uk/ how-it-works (accessed 30 November 2019). 